a nauka ta nie jest nauka praktyczna, bo nie można oddziaływać na Boga. To właśnie stwierdzenie rozpoczęlo spór $-z$ Tomaszem polemizowało wielu autorów: Idzi Rzymianin sądził, że głównym celem teologii jest caritas, a zatem jest to nauka afektywna (nie praktyczna), z kolei Gotfryd z Fontain uważał, że teologia nie ma jednego przedmiotu - podobny pogląd podzielało środowisko franciszkańskie: Jan Duns Szkot sformułował tezę, że przedmiotem nauki jest Bóg, ale jest ona praktyczną. Wilhelm Ockham przedstawił natomiast poglad, że twierdzenia teologiczne wyrażone są w postaci pewnych zdań, które sa teoretyczne i praktyczne, zatem teologia jako zbiór takich zdań ma obie postacie. Grzegorz z Rimini próbował wyjść z impasu twierdzac, że Ockham miał rację, ale zdania te tworzą system o strukturze piramidy, konkludując, że teologia jest praktyczna, mówi ona bowiem jak należy kochać Boga.

Sesję zakończył referat Andrzeja Włodarka (Toruń), który zajął się przestrzenią architektoniczną średniowiecznego uniwersytetu krakowskiego. Uniwersytet był instytucją organicznie zwiazaną z miastem i poprzez swoje instytucje wpisywal się w przestrzeń miasta. Referat omawiał sposoby nabywania przez Akademię Krakowską kolejnych gmachów, metody ich adaptacji na potrzeby dydaktyczne. A. Włodarek skrupulatnie przedstawił dzieje poszczególnych gmachów uniwersyteckich.

Przestawione przez referentów zagadnienia doskonale ukazują różnorodność pytań badawczych stojących przed uczonymi wielu specjalności, zgłębiającymi wspaniałą przeszłość uniwersytetów i ludzi je tworzacych.

Krzysztof Ratajczak

\title{
II Krajowa Konferencja Naukowa „Przeszłość polskiej kultury fizycznej”
}

W dniach 16 - 18 września 2002 roku w Krakowie odbyła się II Krajowa Konferencja Naukowa pt.: „Przeszłość polskiej kultury fizycznej”. Konferencja organizowana była w ramach Jubileuszu 75-lecia Akademii Wychowania Fizycznego.

Jej organizatorami był Instytut Nauk Humanistycznych Akademii Wychowania Fizycznego oraz Zakład Historii Oswiaty i Kultury Uniwersytetu Jagiellońskiego.

Referenci sesji reprezentowali następujace ośrodki: Uniwersytet Jagielloński, AWF Warszawa, AWF Kraków, AP Kraków, AWF Wrocław, AWF Poznań, Uniwersytet im. Adama Mickiewicza w Poznaniu, Uniwersytet Rzeszowski, AWF Katowice, AWF Gorzów Wlkp., WSP Częstochowa.

Przybyłych gości powitał i konferencję otworzył prof. dr hab. Janusz Zdebski. Inauguracyjny wykład wygłosił Prorektor prof. dr hab. Ryszard Winiarski.

Wystapienia przedpołudniowe pierwszego dnia obrad, prowadzone przez prof. Janusza Zdebskiego, poświęcone były roli Krakowa w życiu społeczeństwa polskiego na przelomie XIX i XX wieku oraz dziejom krakowskiej Akademii Wychowania Fizycznego.

Z uwagi na duże swobody autonomiczne Galicja stała się terenem, gdzie szczególnie pielęgnowano polskie tradycje i jubileusze. Kraków stał się miejscem pielgrzymek narodowych oraz narodowego patnictwa. Obchodzono tu uroczystości, których nie wolno było celebrować w innych zaborach. Krakowskie instytucje akademickie skupiały i spełniały wszystkie funkcje naukowe pozostałych polskich dzielnic. Uniwersytet stal się miejscem zjazdów oraz ośrodkiem badań naukowych. Prezentując ówczesny obraz Krakowa oraz podkreślając jego znaczenie prof. dr hab. Julian Dybiec nazwał go „Polskimi Atenami”.

W swoim wykładzie prof. dr hab. Kazimierz Toporowicz zwrócił uwage, że przyjęty stereotypowo rok 1927 nie stanowi rzeczywistego poczatku uniwersyteckiej idei wychowania fizycznego. Z dokumentów źródłowych wynika, że idea ta zrodziła się dużo wcześniej. Kurs Naukowy oraz Studium Wychowania Fizycznego były pionierskimi w tym względzie. Okres, na który przypada początek 
działalności Akademii Wychowania Fizycznego, był niezwykle trudny. Jednak dzięki subwencjom i wielkiemu zaangażowaniu władz Akademia mogła prowadzić swoją aktywność. Warto dodać, że mury uczelni opuściło wielu znanych trenerów oraz olimpijczyków.

Tematyka obrad popołudniowych, prowadzonych przez prof. dr hab. Ryszarda Wasztyla, poświęcona była wychowaniu fizycznemu i jego historii na terenie państwa polskiego. W swoim referacie prof. dr hab. Karol Poznański przedstawił narodziny troski o higienę osobista i zdrowie w XVIII wieku. Porównania stanu higieny oraz poziomu wychowania fizycznego w prawie szkolnym KEN, w Księstwie Warszawskim oraz Królestwie Polskim dokonal prof. dr hab. Leonard Szymański. Kolejne referaty poświecone zostały aktywności ruchowej w świetle poglądów lekarzy polskich z początków XIX wieku, edukacji fizycznej młodzieży z grup skautowych, kształceniu nauczycieli wychowania fizycznego w pierwszym okresie niepodleglej Polski.

Drugi dzień obrad rozpoczał wykładem prof. dr hab. Ryszard Wasztyl przedstawiając historię polskiej i krakowskiej lekkoatletyki. Szereg referatów poświęconych zostało tematyce zwiazanej z powstaniem i działalnościa gniazd "Sokoła” oraz rozwojowi sportu i jego nowych dyscyplin na różnych terenach Polski w XX w.

Wystapienia popoludniowe przedstawiały wkład różnych organizacji i fundacji w rozwój polskiego wychowania fizycznego oraz politykę władz w tym zakresie.

W ostatnim dniu obrad prof. dr hab. Mirosław Ponczek omówił genezę polskiej turystyki zorganizowanej w Zaglębiu Dabrowskim do momentu wybuchu II wojny światowej. Kolejne wykłady traktowały o rozwoju takich dziedzin sportu, jak: narciarstwo, taternictwo i alpinizm. Na zakończenie omówione zostały konotacje pojęcia ,sport" w dawnych i współczesnych ideologiach wspinaczkowych.

W czasie dyskusji nad referatami podniesiono kwestię konieczności wcześniejszego drukowania wykładów w celu głębszego ich przeanalizowania. Zaznaczono też potrzebę rozpoczęcia badań nad początkiem kształcenia nauczycieli wychowania fizycznego na poziomie akademickim oraz możliwość zorganizowania konferencji na wspomniany temat.

Podsumowaniem przedstawionych referatów był postulat dokonania zestawienia bibliografii i oceny stanu badań dziejów wychowania fizycznego w Polsce.

Joanna Kowalska-Matelska

\section{Ogólnopolski Zjazd Pedagogiczny w Olsztynie - Sekcja XIV: „Dzieje Europy i dzieje edukacji dla wspólnego świata"}

W dniach 20 - 22 września 200 I roku obradował w Olsztynie IV Ogólnopolski Zjazd Pedagogiczny. Obok obrad plenarnych, $\mathrm{z}$ racji na duże zainteresowanie i szerokie zainteresowania uczestników, toczyły się rozmowy i prelekcje w 20 sekcjach. Jedną z nich była Sekcja XIV, obradująca w Audytorium prof. E. Pijanowskiego, pod hasłem: „Dzieje Europy i dzieje edukacji dla wspólnego świata”.

Przewodniczacymi Sekcji XIV byli: prof. dr hab. Alicja Kicowska z Wydziału Pedagogiki i Wychowania Artystycznego Uniwersytetu Warmińsko-Mazurskiego w Olsztynie i prof. dr hab. Wiesław Jamrożek, pracownik Wydziału Studiów Edukacyjnych Uniwersytetu im. A. Mickiewicza w Poznaniu. Uczestnikami obrad zaś byli przedstawiciele 16 ośrodków naukowych, reprezentujący w większości środowisko poiskich historyków wychowania. Sekcja gościła także badacza z Kanady, prof. dra Kas Mazurka $z$ Uniwersytetu w Lethbridge w Kanadzie.

Pierwotnie zaplanowano 48 wystapień, wysluchano ich jednak mniej, bo 31 . Zostały one zaprezentowane $w$ pięciu blokach tematycznych: „Ku najwyższym wartościom - tradycje polskiej edukacji”, „Regionalizm w badaniach historyczno-oświatowych”, „Dzieje instytucji i środowisk 